ОРИГИНАЛЬНЫЕСТАТЬИ

\title{
THE VICTORY OF ISLAM OVER THE BUDDHIST RELIGION (REVIEWING THE INSCRIPTIONS OF THE SHRINE OF IMAMZADEH MULLA “MA'SUM" OF MARAGHEH)
}

\author{
Samad Parvin $^{\text {la }}$, Saeid Sattarnejad ${ }^{1 b}$, Elham Hendiani ${ }^{2}$ \\ ${ }^{1}$ University of Mohaghegh Ardabili \\ Ardabil, Iran \\ aarjaan1370@gmail.com, ${ }^{b}$ saeidsattarnejad@yahoo.com \\ ${ }^{2}$ Tabriz Islamic Art University \\ Tabriz, Iran \\ el.hendiani@gmail.com
}

\begin{abstract}
Research objectives: The main purpose of this article is to study the Quranic inscription of the Imamzadeh Ma'sum Temple in Maragheh. This inscription shows the evolution of religious beliefs during the Ilkhanid period in Iran which started from the seventh century $\mathrm{AH}$ and continued until the eighth century $\mathrm{AH}$. The main religions of the Ilkhanid rulers were Buddhism and Christianity, but they gradually adopted Islam as the official religion of government. The influence of the process of conversion has left traces in some of the inscriptions of this period. Another purpose of this study is to introduce the Imamzadeh Ma'sum temple as one of the Buddhist temples in Iran.

Research materials: In this study, the authors have used two methods, namely field research and library surveys. Regarding the first method, the temple of Imamzadeh Ma'sum was examined. Regarding the second method, the historical sources of the Ilkhanid period, such as the Jami' al-tawarikh of Khajeh Rashid al-Din Faḍlullah Hamadani, were used. These works refers to the situation of Buddhists in Iran during the Ilkhanid period (i.e. the seventh century $\mathrm{AH}$ ).

Results and novelty of the research: The results of the authors' research in this article have demonstrated that the temple of Imamzadeh Ma'sum of Maragheh was one of the Buddhist temples in Iran. This Buddhist temple was changed to an Islamic mosque after the conversion of Ghazan Khan in 694 AH. The surviving Qur'anic inscription inside the building refers to the victory of Islam over Buddhism.
\end{abstract}

Keywords: shrine of Imamzadeh Mulla Ma'sum, inscriptions, rock-cut architecture, political-religious beliefs, Ilkhanid period

For citation: Parvin S., Sattarnejad S., Hendiani E. The Victory of Islam over the Buddhist Religion (Reviewing the Inscriptions of the Shrine of Imamzadeh Mulla "Ma'sum" of Maragheh). Zolotoordynskoe obozrenie=Golden Horde Review. 2020, vol. 8, no. 4, pp. 636-646. DOI: 10.22378/2313-6197.2020-8-4.636-646 


\section{Introduction}

The following subject has been the title of a study carried out about the rockcut architecture of Maragheh for the past 8 years (2012). Its main task, besides introducing, was determining the performance of rock-cut areas and relative chronology of spaces. The study of rock-cut architecture in Maragheh city is very limited and incomplete. The works studied by local and foreign researchers have been published with contradictory theories. One of the most important features of rock-cut works of Maragheh city is the shrine of Imamzadeh Mulla Ma'sum in Varjovi (Varovi) village, which is one of the most controversial buildings in Iranian architectural history. According to the presented theories, the construction date is between a Mehr (Mithra) temple, Zoroastrian Fire Temple, Khaneqah and Islamic Mosque and even an Imamzadeh. Experts and scholars have cited different dates for the building. The existence of inscriptions engraved within the collection from the beginning could have played a decisive role in recognizing the true identity of the building. The misinterpretation of the text by the earlier scholars in recognizing the error of the verse used in the inscription has diverted the study process from its beginning. Therefore, the purpose of this paper is to provide a complete, accurate, and readable text of the verse used in this collection for the first time and to provide a documented commentary on the inscription's text on the main structure and function of the collection.

\section{Geographical Location}

In East Azarbaijan province, $6 \mathrm{~km}$ south-east of Maragheh city [8, p. 44], and on the route of Takab city [5, p. 1033], a rock-cut architecture with complex plan called Imamzadeh Mulla Ma'sum Varjovi is located. It is called Var-Övi in Turkish language [1, p. 215]. This rock-cut complex is one of the most interesting and carefully crafted cave architectures of Iran [2, p. 330].

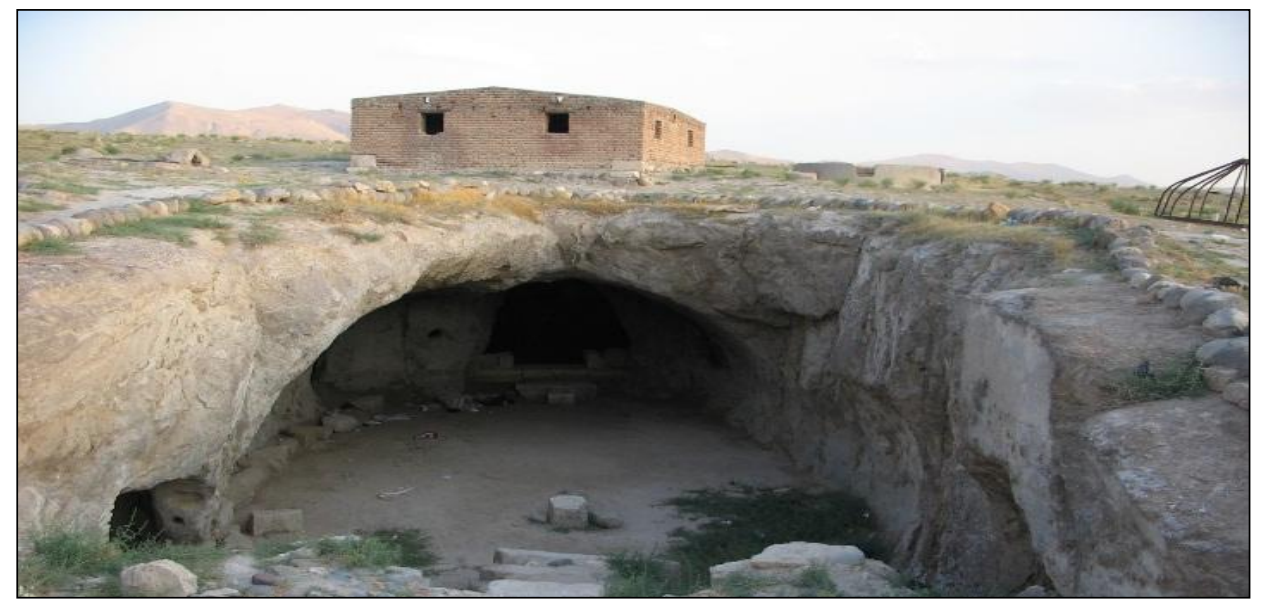

Image 1. The rock-cut shrine of Imamzadeh Mulla Ma'sum

The collection consists of various parts: 1 - entrance part, 2 - central hall, 3 chambers with circular plans, 4 - alcove part (burial place of Imamzadeh Mulla Ma'sum) which has a nearly cruciform or chalipa plan. This collection was first 
registered under the name of Imamzadeh Mulla Ma'sum with register number 788 and re-registered in 1977 under the name of Mehr temple with register number $1556 / 3$ in the National List of Works [11, p. 168]. Based on the writings on tombstones and inscriptions, adjacent to the Varjovi temple is a cemetery dating back to the ninth and tenth century $\mathrm{AH}$. One of the tombstones in the cemetery adjacent to the temple dome has inscriptions that do not resemble any of the Islamic items and lines and have a unique broken script. The date of this inscription is $1069 \mathrm{AH}$. And on the stone figure, the sign of the shield, sword, bow and arrow is imprinted [7, p. 153].

Despite archaeological studies of the rock-cut collection of Imamzadeh Mulla Ma'sum $[2 ; 28 ; 21 ; 7]$, there are many doubts and objections regarding the chronology and performance of the various units. Scholars who have conducted studies of this site with a subjective presupposition based on Mehr temple [8] have continued their research and mistakenly referred to this temple as Mithra temple. In essence, the use of this collection is a Buddhist temple belonging to the Ilkhanid period $[2 ; 1]$. Accordingly, no evidence of Mithraism has been discovered and identified in this collection and similar sites [15]. Therefore, most scholars who have introduced this collection as a Mithra temple have made some mistakes in their research on the functional nature of the various units in the collection, and in particular in identifying the inscribed Qur'anic verse in this building, so that they identified the Qur'anic verse used inside the shrine as verse 129 of Surat al-'Amran [8, p. 44; 28, p. $95 ; 24$, p. 51; 23, p. 115]. In recent archaeological studies, while rereading the Qur'anic verse, the inscriptions were also taken into consideration, and the reasons for choosing these inscriptions for rock-cut shrine of Imamzadeh Mulla Ma'sum were studied and analyzed.

\section{Central Hall Inscription}

Beautiful inscription has been carved in part of the western side wall of the great central hall [7]. In an article entitled as Imamzadeh Ma'sum Varjovi, Varjavand identified the type of script as a Thuluth and read the inscription in verse 129 of Surat al-'Amran. Varjavand's comment on the inscriptions in this collection has led future scholars to cite this scholar's reading and claim that it is a preIslamic Mehr temple [23; 22], which was added to the collection in the Ilkhanid and Safavid inscriptions. According to the reviewing of authors of this article, the full text of the inscriptions in the collection is as follows:

"And to Allah belongs the dominion of the heavens and the earth. He forgives whom He wills and punishes whom He wills. And ever is Allah Forgiving and Merciful"

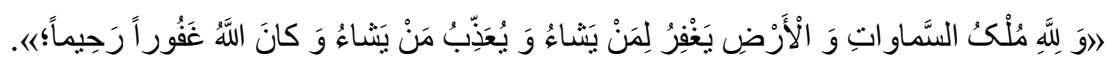

Verse 14 is from Surat al-Mubarak al al-Fath, which was identified verse 129 of Surat al-'Imran in earlier studies by Rajavand [23, p. 51; 22, p. 115]. Also, on the western wall of the entrance gate is left only the inscriptions of the holy word "Allah and" [18, p. 102]. The script used in this inscription is Naskh [7, p. 152], which is one of the calligraphic features of the Ilkhanid period used in the central hall of the Imamzadeh Ma'sum [2, p. 337]. Images 2 and 3 show that the inscription surrounds the entire wall, margins and entrances as a belt [7, p. 150]. 


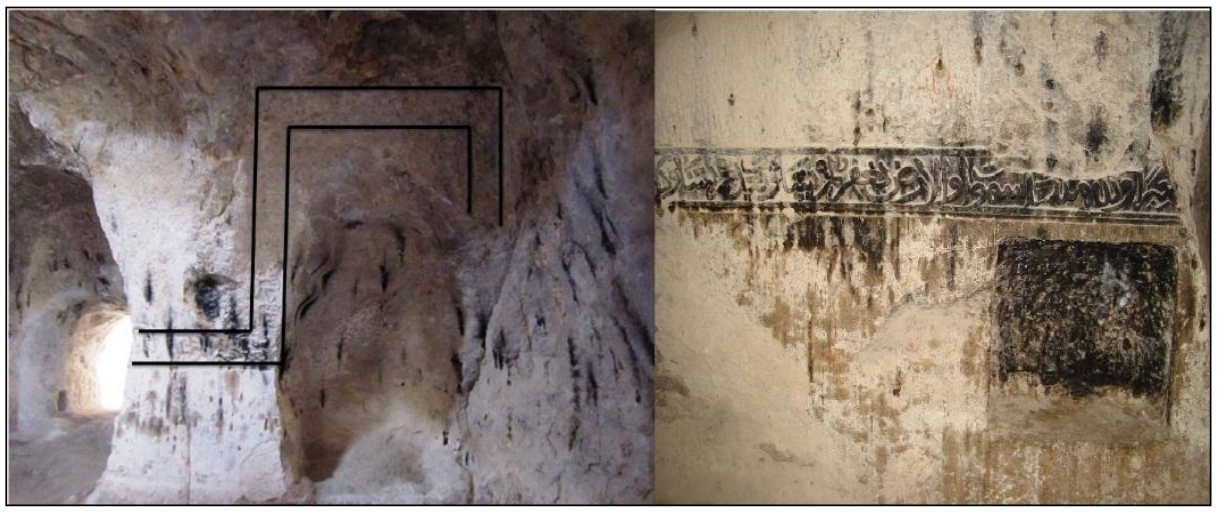

Image 2. The Quranic inscriptions of the collection of the Imamzadeh Ma'sum (the authors')

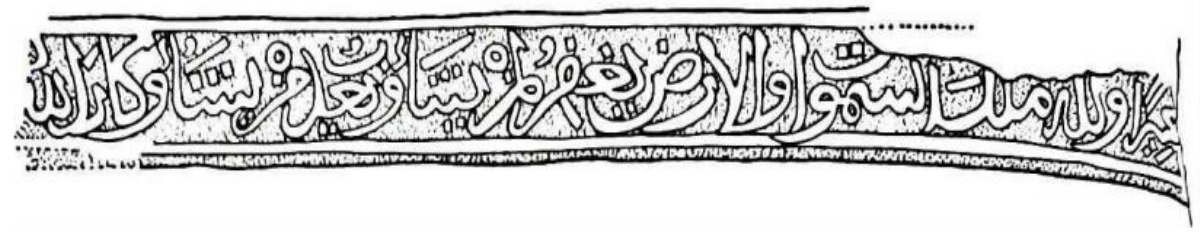

Image 3. Design of the Quranic Inscription [2, p. 339]

\section{Type of Building, Date of Construction and Architectural Style}

The vast expanse of the collection and being a cave like Mehr temples identified in the pre-Islamic era in the territory of the ancient Roman Empire is the first point that has drawn scholars' attention to the pre-Islamic period [8, p. 44]. Although some Iranian scholars refer to caves that they like to be Mehr temples, they have not provided sufficient evidence to attribute the above caves to Mehr [15, p. 29].

Rocky architecture with its cave-like form is not exclusive to Mithra religion. It has been formed in different cultures according to specific beliefs. Also, despite numerous rock artifacts in the northwest region, such an architectural style, particularly dome and vault form, is unknown. In rock architecture until the Achaemenid period, surfaces are flat and right-angled without curved lines in doorways and ceiling coverings. The covering of Fakhriika Manai's Catacomb is flat, right angled and well-carved [12, p. 362]. The ceiling of the tomb of Ismaili Agha is very rough and irregularly carved, which belongs to the seventh century AH according to the found potteries. [19, p. 7]. But in the Parthian period, these coverings have become bent and curved. The reasons for the transformation of architectural elements from flat to curved can be attributed to the advancement of architecture, especially the progress of Iranians in the creation of arches using more conventional materials without the need for more durable wood. This change has been noticeable from the Parthian period.

The dome cover used in this collection is related to the Islamic period [2]. This style of rock architecture can be considered a common method in rock formations during the Ilkhanid period, such as the Cave Observatory Collection [1], Ghadamgah of Azarshahr [7]. Also, the debris removals (one meter in deep) from 
the floor of the shrine collection, decorative elements such as the niches, the Islamic role used in the collection, and the half-way carving of the collection indicate that the building dates back to the Islamic period, which has been created by using khanqah and the mosque [7]. On the other hand, the possibility of adding inscriptions to the collection in later periods [28] could still be a subject of discussion. A careful examination of the inscription's style indicates that the inscription was later inserted into the Gaza Khanate period. Accordingly, it is necessary to pay close attention to the political and religious concepts used in the inscription.

\section{The Content of the Inscription Text}

Inscriptions are the only visual elements that directly carry meaning and are of great importance in two aspects, image (appearance) and content and text in the buildings of Islamic period of Iran [10, p. 30]. The main message of architecture was conveyed directly through the inscriptions. Inscriptions, as one of the most important historical sources, play an important role in revealing the identity of architectural spaces, methods of construction, administration, supporters, etc. These buildings provide information that gives us historical insight into the economic, political, and social reform issues.

In terms of communication with the viewer, the inscriptions also contain different messages and are written in different forms, with different lines in different languages. The artistic and visual values of the inscriptions are always of interest. For this reason, inscriptions can represent some of the cultural characteristics, thoughts, beliefs, and behaviors and are important from a decorative, historical-religious point of view [26, p. 82]. On this basis, inscriptions are considered as one of the most documented evidence in the research on a monument and have always been preferred to historical quotations. And many changes and evolutions of society can be found in the inscriptions [10, p. 31].

The inscriptions used in the collection of the rock-cut of Imamzadeh Mulla Ma'sum are verses of Surah al-Fath. Surah al-Fath is the Forty-eighth Surah of the Holy Quran, which is Madani and it has 29 verses. This Surah is called "al-Fath" and means victory. At the beginning, it speaks of the conquest of God (the glorious victory). Commentators disagree as to which victory this conquest refers to [4, p. 125]. While some consider it as the conquest of Khyber and some have pointed to the victory of Islam over all enemies through the power of logic and the supremacy of obvious reasons and miracles [9, p. 10], thus, the text of the verse refers to the conquest of Khyber, which indicates the confrontation of Muslims with the Jews. It is also stated in the traditions that the Prophet (peace be upon him) said: "Whoever reads the Surah of al-Fath is like one who was present with the Prophet in al-Fath". In another narration, it was stated that: The virtue of Qari Surah is like that it was present with the Prophet in the conquest of Mecca [25, p. 181].

Imam Sadiq (peace be upon him) said: "Keep your wives and your children away from harm by reading Surat al-Fath, because everyone who continues to read it, on the Day of Resurrection, will pray for the creature to hear that you are one of my pure servants, and saying: Join him in my righteous and righteous servants, and bring him to my blessings in Paradise, and make him drink of the wine of the seal, which is in the taste of camphor" [17, p. 115]. 
Based on Shi'ite narrations and commentary books, the theme of Surat al-Fath first refers to the victory of Muslims over other religions, especially the two Jewish and Quraysh tribes. After these events, "Islam" was chosen as the official religion of Islamic countries including Iran. But with the Mongol invasion of Iran and the formation of government by them, the existing political, social, and religious structures and frameworks has been changed. Before the Mongol invasion, all postIslamic Iranian governments in Iranian history derive their legitimacy from the Abbasid caliphate. The Mongol invasion and their pervasive domination over the pillars of Iranian power and wealth changed the existing equilibrium of political, economic, and religious power and transformed political and ideological groupings and tendencies [27, p. 126]. Although the Mongols had no particular religious orientation or prejudices, it should be said that the Ilkhanid religious tolerance policy was more to the benefit of religious groups and minorities, and even in many cases, it has been to the detriment of the majority of Iran's Muslim community [14, p. 123].

According to historical texts in the Ilkhanid period, a group of Mongols tended to the Buddhist religion, and Buddhist temples were scattered throughout Iran [24, p. 187]. Hulagu ordered the construction of houses in Khoy [16, p. 1048]; this tendency towards the Buddhist religion provided a good basis for the spread of this religion in Iran, so that floods of consultants and Buddhist monks poured into Iran from China, Tibet, the Uighur land and even India. The influence of this religion in western Iran became more apparent and Maragheh, Khoy, Aran became suitable places for temples and pagodas [3, p. 375]. A number of Ilkhanids were also the followers of the Buddhist religion and took the advice of Buddhist, just as Hulagu and Abagha had Buddhist advisers in their court. One of them can be mentioned: Janglawan, who was one of his great advisers to the Buddhist sect [16, p. 1179]. Or Arghun Aqa, a noble of the Oirat tribe, who was a bitikchi (secretary and tax collector). He also had the knowledge of music and was appointed as the ruler of Khorasan. Due to the presence of Buddhists in the observatory complex [16, p. 1179], we are witnessing the establishment of Buddhist residences in this city $[13$, p. 66]. But the ascension of Ghazan Khan led to fundamental reforms in the political and religious structure of the Ilkhanids. The victory of Ghazan Khan, the Muslim ruler, eradicated the Buddha's religion at once. Buddhist temples were plundered and destroyed, or converted into mosques [24, p. 192]. Accordingly, the Buddhist temples of Maragheh were destroyed and burned [20, p. 88]. And it changed into a shrine and a mosque. Accordingly, the theme of the Qur'anic verse of the shrine of Imamzadeh Mulla Ma'sum, similar to the developments in the early days of Islam, which referred to the triumph of Islam over the Jewish people, also refers to the predominance of Islam over the Buddhist religion.

It is worth mentioning that it has also been studied by some archaeologists and rock architectural experts from the point of view of architecture and archaeology. Based on this review, this is a Warwick Ball's article that has done a great deal of research on the rock architecture of Iran and Afghanistan. He has carefully examined this collection or complex and considered it as Islamic (Ilkhanid) building [2]. Kambakhsh fard also rejected any possibility of the temple being a secret of this work and confidently regards it as an Islamic work [7]. There are also explicit references to historical texts, much like the rocky temples of Maragheh, and the Hindu temples themselves have an Islamic (Buddhist temple) reason. The 
study and classification of the surface pottery also belonged mainly to the Ilkhanid and Safavid period and no pottery belonging to the historical period was identified.

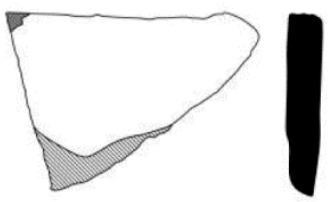

N 7

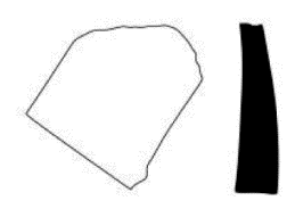

N 9

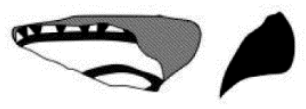

N 11

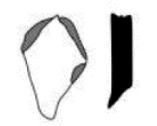

N 13

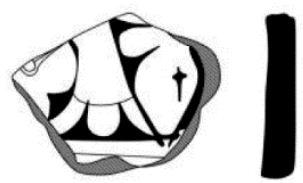

N 8

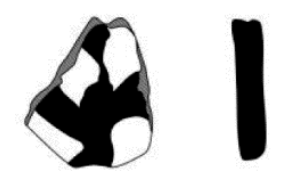

N 10

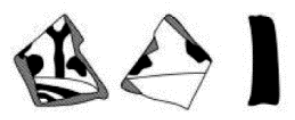

N 12

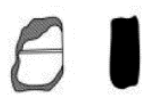

N 14

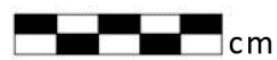

Image 4. Design of pottery

Results

Due to the unique features of the collection of rock-cut architectural works, the best way to find out the earliest time of collection creation is by inscription or writing. Accordingly, prioritizing any conjecture before obtaining explicit and correct inscriptions will not yield the right result.

For the following reasons, relying on a complete re-reading of the complete text of the remained rocky inscription, we can now speak more confidently about the construction date for the following five reasons:

The verse used in this inscription is verse 14 of Sura al-Fath; Surat al-Fath is one of those Qur'anic suras that were built during the Ilkhanid period in buildings such as the altar of the jame masjid (congregational mosque) of Saveh (seventh century AH), the jame masjid of Bastam (702 AH), jame masjid of Farfan (eighth century $\mathrm{AH}$ ), jame masjid of Varamin (722 AH), jame masjid of Abargho (738 $\mathrm{AH})$, Kermani Mosque (eighth century AH). It has been also used in the tomb of Sheikh Haydar of Meshkinshahr (731 AH), Soltanieh dome of Zanjan and the great 
jame masjid of Yazd. These monuments date back to the reign of Ghazan Khan and the formalization of the religion of Islam. Since inscriptions in Iranian architecture reflect the social, religious and cultural conditions of their writing, the artists and architects of the Ghazan Khan's era, by choosing verses from Surat al-Fath, show the superiority and triumph of Islam over other religions, especially the Buddhist religion, which had an important place in the structure of the Ilkhanid government in the early Ilkhanid period. Accordingly, the purpose of selecting Surat al-Fath in this shrine is to triumph over Buddhism and to change the paganism to Islamic worship. The inscription theme refers to the victory of Islam over other religions; the emphasis on historical texts refers to the differences between Muslims and other religions, especially Buddhists and Christians in the Ilkhanid period, which, like the conquest of Kheybar and Mecca in the early Islamic period, is the ultimate victory for Muslims, who triumphed over other religions in the Ilkhanid era after the reign of Ghazan Khan.

A stylistic study of the pre-Islamic rocky architecture of the area reveals the major differences between this collection and other pre-Islamic rock works in the region.

According to the excavation of one meter from the complex floor, no traces of Mithraism have been discovered and identified.

Careful study of archaeologists with specialization in rock architecture such as Warwick Ball and archaeologists such as Kambakhsh fard who have excavated the Anahita Kangavar sanctuary, confirms the assignment of this complex to the Islamic period.

\section{Note}

The appellation of the region's names such as Pir Hashim, Khanqah, and Sufichai, also show the relevance of this collection to the Islamic period.

Excavating of the complex were carried out in the decade of $2000 \mathrm{AD}$ when only a few tombs of the Islamic period were identified on the complex floor and no evidence of pre-Islamic period was discovered.

Six rocky temples were identified by an archaeological study on the architecture of the handwriting [18], which appears to be a Buddhist temple, near the temples of Kohulu Machid and the yard of Pir Hashim of Varjovi village, which is a Buddhist temple. After the religious reforms of Ghazan Khan, it became a mosque.

\section{REFERENCES}

1. Azad A. Three rock-cut cave sites in Iran and their Ilkhanid Buddhist aspects reconsidered. Islam and Tibet: Interactions along the Musk Routes. Akasoy A. et al. (eds). London; New York: Routledge, 2016, pp. 209-230.

2. Ball W. The Imamzadeh Masum at Vardjovi: A rock-cut Il-khanid complex near Maragheh. Archäologische Mitteilungen aus Iran Berlin. 1979, vol. 12, pp. 329-340.

3. Bayani Sh. دين و دولت در ايران عهد مغول [Religion and Government in Iran]. Tehran: University Press, 1992. 1108 p. (In Persian)

4. دانشنامه قرآن و قر آن يزّوهى ـ [Encyclopedia of Quran and Quran Studies]. Khorramshahi B. (ed.). Tehran: Friends, Nahid, 1998. 4766 p. (In Persian) 
5. Alijabari Z. and Farahinia A.H. Analyzing architecture of Mithraism rock temples. Journal of History Culture and Art Research. 2017, Vol. 6, no. 3, pp. 1030-1042.

6. Ghirshman R. هنر ايران در دوره ماد و هخامنشى [Iranian Art in the Medes and Achaemenian Periods]. Behnam I. (tr.) Tehran: Scientific and Cultural Publications, 1992. 415 p. (In Persian)

7. Kambakhsh fard S. Kررسى هاى باستانشناسى آذرشهر و مر اغه، حرفى ديكر درباره ساختمان جند [Archaeological surveys of Azarshahr and Maragheh: Another word about the construction of Khaneqah and mosques]. مجله ميراث فر هنكى [Journal of Cultural Heritage]. 1994, no. 12, pp. 1-23. (In Persian)

8. Karang A. آثار تاريخى مراغه[Historical works of Maragheh]. Tehran: Education Publications, 1971. 64 p. (In Persian)

9. Makarem Shirazi N et al. تفسير نمونه [Tafsir Nemooneh]. Qom: Dar al-kotob Islamiyah, 1995. 580 p. (In Persian)

10. Makinejad M. سير تحول كتيبههاى ثلث در معمارى ايران صفوى تا قاجار ] [The evolution of the Thuluth script in Iranian architecture from the Safavid to Qajar periods]. مجله نكره [Nagare Magazine]. 2009, no. 13. pp. 29-40. (In Persian)

11. Mokhlesi M.A. فهرست بناهاى ناريخى آذربايجان [List of Monuments of Azerbaijan]. Tehran: National Heritage Organization publication, 1992. 236 p. (In Persian)

12. Molazadeh K. باستانشناسى ماد [Median Archaeology]. Tehran: Samt Publications, 2014. 488 p. (In Persian)

13. Morgan D. Medieval Persia 1040-1797. London: Routledge, 2015. xvii + 198 p.

14. Nojavan M.بررسى اصلاحات غازانخان (دوره ايلخانى) [A Study of the Reforms of Ghazan Khan (Ilkhanid Period)]. Master's Thesis in History. University of Urmia, 2014. 150 p. (In Persian)

15. Rahbar M. معمارى معابد مهرى در ايران [Architecture of Mehri temples in Iran]. مجله كند وكاو[Excavation Magazine]. 2013, no. 8. pp. 28-41. (In Persian)

16. Rashid al-Din F. جامعالتواريخ [Jami' al-tawarikh]. Volume II. Karimi B. (ed.). Tehran: Eqbal, 1994. 1539 p. (In Persian)

17. Saduq M. ثَوَاب الأعمال و عِقاب الأعمال [Thawāb al-a māl wa 'iqāb al-a'māl]. Qom: Dar al-Sharif al-Razi, 1985. 672 p. (in Arabic)

18. Sattarnejad S. مطالعه و بررسى باستانشناختى معمارى دستكند شهرستان مراغه [Archaeological Study and Survey of Troglodytic Architecture in Maragheh County]. MA Thesis of Archaeology. University of Mohaghegh Ardabili, 2016. 180 p. (In Persian)

19. Sattarnejad S., Parvin S., Mastalizadeh M. Stylistic study of Gowijeh Qaleh's rock-cut tomb from Maragheh. ANASTASIS. Research in Medieval Culture and Art. 2020, Vol. 7, no. 1, pp. 1-10.

20. Sattarnejad S., Shahbazi shiran H., Maroufi E. بررسى و تحليل ماهيت كاربردى معمارى [Study and analysis of the rock architectural Hill Rasadkhaneh at

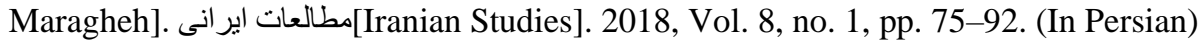

21. Shakari Niri J. معمارى صخرهاى در آذربايجان و زنجان [Rock architecture in Azerbaijan and Zanjan]. Tarbiat Modarres University, 1993. 200 p. (In Persian)

22. Shakari Niri J. مامز اده معصوم مراغه معبد مهريرستى ايران و نشانها در معابد ارويايیى[Imamzadeh Mulla Ma'sum of Maragheh: Temple of Iranian Mithraism and symbols in European temples]. مطالعات ايرانى[Iranian Studies]. 2006, no. 10, pp. 109-125. (In Persian)

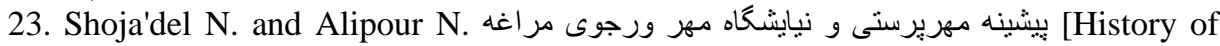
Mithraism and Mehr Temple of Varjovi in Maragheh]. مجله تاريخ بزّوهى :History Research Journal]. 2005, no. 24, pp. 44-54. (In Persian)

24. Spuler B. تاريخ مغول در ايران [Mongolian History in Iran]. Mirafatab M. (ed.). Tehran: Cultural and Scientific Publications, 1989. 563 p. (In Persian) 
25. Tabarsi F. مجمع البيان فى تفسير القرآن [Majma“ al-Bayan fi-Tafsir al-Qur'an]. Vol. 8. Mohammad Javad Balaghi (ed.). Tehran: Naser Khosro Publications, 1993. 191 p. (In Persian)

26. Taghizadeh Alameh and Javad Ali Mohammadi Ardakani.-بررسى و تحليل نوشتار (كتيبه نكارى) بامثنابه رسانهى تبليغاتى در معمارى ايران [Investigating and analyzing writing as advertising

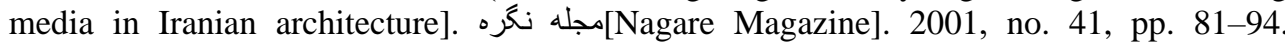
(In Persian)

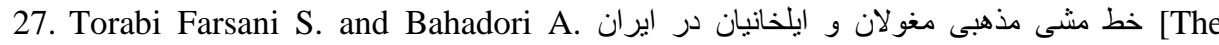

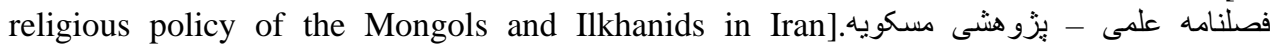
[Maskooyeh Scientific and Research Quarterly]. 2011, no. 18, pp. 105-125. (In Persian)

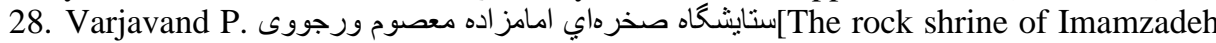
Ma'sum Varjouy]. مجله بررسى هاى تاريخى [Journal of Historical Reviews]. 1972, no. 5, pp. 39. (In Persian)

About the authors: Samad P. Parvin - Graduate of Archaeology, University of Mohaghegh Ardabili (University Str., Ardabil 5619911367, Iran). E-mail: arjaan1370@gmail.com

Saeid S. Sattarnejad - Ph.D. student of archaeology of Islamic periods, University of Mohaghegh Ardabili (University Str., Ardabil 5619911367, Iran): E-mail: saeidsattarnejad@yahoo.com

Elham H. Hendiani - Tabriz Islamic Art University (Azadi Blvd., Hakim Nizami Ganjavi Sq., Tabriz 5164736931, Iran). E-mail: el.hendiani@gmail.com

\title{
ПОБЕДА ИСЛАМА НАД БУДДИСТСКОЙ РЕЛИГИЕЙ (РАССМОТРЕНИЕ НАДПИСИ НА ХРАМЕ МУЛЛЫ ИМАМ-ЗАДЕ МАС'УМА В МАРАГЕ)
}

\author{
Самад Парвин ${ }^{l a}$, Саеид Саттарнейад ${ }^{1 b}$, Элхам Хендиани ${ }^{2}$ \\ ${ }^{1}$ Университет Мохагег Ардабили \\ Ардебиль, Иран \\ a arjaan1370@gmail.com, ${ }^{b}$ saeidsattarnejad@yahoo.com \\ ${ }^{2}$ Университет исламского искусства Тебриза \\ Тебриз, Иран \\ el.hendiani@gmail.com
}

Цель исследования: изучить кораническую надпись храма Имам-заде Мас'ума в Мараге. Эта кораническая надпись показывает изменение религиозных верований в период Ильханидов в Иране. Период Ильханидов начался с седьмого века хиджры в Иране и продолжался до восьмого века хиджры. Основными религиями Ильханидских правителей были буддизм и христианство, но они постепенно приняли ислам в качестве официальной религии своего правления. Влияние процесса религиозного обращения отразилось в некоторых надписях этого периода. Еще одной целью ис- 
следования является стремление представить храм Имам-заде Мас'ума в качестве буддийского храма в Иране.

Mатериалы исследования: в этом исследовании авторы использовали два метода: полевого исследования и библиотечных изысканий. Полевым методом был исследован храм Имам-заде Мас'ума. Затем были привлечены исторические источники периода Ильханидов, такие как Джами ат-таварих, написанный Рашид ад-дином. В этом сочинении говорится о положении буддистов в Иране в эпоху Ильханидов (седьмой век хиджры).

Результаты и новизна исследования: авторы статьи впервые показали, что храм в Мараге был одним из буддийских храмов в Иране. Этот буддийский храм был преобразован в исламскую мечеть после обращения Газан-хана (694 г. хиджры). Сохранившаяся кораническая надпись внутри здания указывает на победу ислама над буддизмом.

Ключевые слова: храм Имам-заде Мас'ума, надписи, высеченная в скалах архитектура, политико-религиозные верования, период Ильханидов

Для цитирования: Parvin S., Sattarnejad S., Hendiani E. The Victory of Islam over the Buddhist Religion (Reviewing the Inscriptions of the Shrine of Imamzadeh Mulla "Ma'sum" of Maragheh) // Золотоордынское обозрение. 2020. Т. 8, № 4. С. 636-646. DOI: $10.22378 / 2313-6197.2020-8-4.636-646$

Сведения об авторах: Самад П. Парвин - магистр (археология), Университет Мохагег Ардабили (University Str., Ardabil 5619911367, Iran). E-mail: arjaan1370@gmail.com

Саеид С. Саттарнейад - докторант (археология исламского периода), Университет Мохагег Ардабили (University Str., Ardabil 5619911367, Iran): E-mail: saeidsattarnejad@yahoo.com

Элхам Х. Хендиани - Университет исламского искусства Тебриза (Azadi Blvd., Hakim Nizami Ganjavi Sq., Tabriz 5164736931, Iran). E-mail: el.hendiani@ gmail.com 